\title{
ANALIZA SYSTEMU MOTYWACYJNEGO PRACOWNIKÓW KADRY ADMINISTRACYJNEJ JEDNOSTKI SEKTORA PUBLICZNEGO
}

\section{ANALYSIS OF THE INCENTIVE SCHEME FOR THE ADMINISTRATION STAFF OF PUBLIC SECTOR UNITS}

\author{
Daniel Tokarski $^{1(A, B, C, D, E, F, G)}$, Agnieszka Smarzewska $^{2(A, D, E, G)}$, Adam Szepeluk $^{3(C, D)}$ \\ ${ }^{1}$ Regionalne Centrum Badań środowiska, rolnictwa i technologii innowacyjnych EKO-AGRO-TEC, Państwowa \\ Szkoła Wyższa im. Papieża Jana Pawła II w Białej Podlaskiej \\ ${ }^{2}$ Państwowa Szkoła Wyższa im. Papieża Jana Pawła II w Białej Podlaskiej \\ ${ }^{3}$ Centrum Badań nad Innowacjami w zakresie zdrowia, technologii informatycznych oraz źródeł energii \\ odnawialnej, Państwowa Szkoła Wyższa im. Papieża Jana Pawła II w Białej Podlaskiej
} Tokarski, D., Smarzewska, A., Szepeluk, A. (2018). Analiza systemu motywacyjnego pracowników kadry administracyjnej jednostki sektora
publicznego. Rozprawy Społeczne, 12(2), 65-72. https://doi.org/10.29316/rs.2018.16

Wkład autorów:

A. Zaplanowanie badań

B. Zebranie danych

C. Dane - analiza i statystyki

D. Interpretacja danych

E. Przygotowanie artykułu

F. Wyszukiwanie i analiza

literatury

G. Zebranie funduszy

Tabele: 3

Ryciny: 7

Literatura: 15

Otrzymano: czerwiec 2017

Zaakceptowano: listopad 2017

\section{Wstęp}

Motywacja pracowników to jeden z głównych elementów składowych zarządzania przedsiębiorstwem. Dlatego też niezwykle ważne jest określenie i zdefiniowanie $\mathrm{w}$ przedsiębiorstwie najistotniejszych motywatorów, to jest czynników, które

\begin{abstract}
Streszczenie
Wstęp. Przedmiotem badań była ocena opinii pracowników kadry administracyjnej jednostki sektora publicznego w tym przypadku Uczelni Wyższej nt. wewnętrznego systemu motywacyjnego. Celem pracy było określenie najbardziej istotnych bodźców motywacyjnych z uwzględnieniem podziału na motywatory płacowe oraz pozapłacowe.

Materiał i metody. Badanie zrealizowano przy pomocy kwestionariusza ankiety online, na zasadzie doboru celowego respondentów, tj. każdy pracownik administracyjny otrzymał maila $\mathrm{z}$ linkiem do kwestionariusza ankiety wraz z prośbą o wzięcie udziału w badaniu.

Wyniki. Badania własne przeprowadzane za pomocą kwestionariusza ankiety wykazały, iż głównymi czynnikami motywującymi pracowników administracyjnych do pracy są m.in.: wysokość wynagrodzenia zasadniczego, możliwość awansu, zmiana stopnia zaszeregowania, stabilność zatrudnienia, skonkretyzowane i jasno wyznaczone cele oraz premia uznaniowa.

Wnioski. Płacowe czynniki motywacyjne sa dla respondentów kluczowe w procesie samorealizacji i zadowolenia z wykonywanej pracy. Oznacza to, że pracownicy najbardziej cenią sobie fakt stałej, dobrze płatnej pracy z możliwością rozwoju.
\end{abstract}

Słowa kluczowe: efektywność, motywacja, rozwój zawodowy, satysfakcja, wydajność

\begin{abstract}
Summary
Introduction. The subject of the research was the assessment of the opinions held by the administration staff of a public-sector unit - in this case of a University - on the subject of internal incentive system. The aim of the work was to determine the most important motivational incentives, including the division into remunerative and non-remunerative motivators.

Material and methods. The survey was carried out using an online questionnaire, on the basis of targeted selection of respondents, i.e. each administration employee received an e-mail with a link to the questionnaire, along with a request to participate in the survey.

Results. Proprietary research carried out using a questionnaire survey showed that the main factors motivating administration employees to work are, among others, basic salary amount, promotion opportunities, change of rank, stability of employment, specific and clearly defined goals and discretionary bonus.

Conclusions. Remunerative motivational factors are crucial for the respondents in the process of personal fulfillment and satisfaction with the work performed. This means that employees appreciate a stable, well-paid job with development opportunities.
\end{abstract}

Keywords: efficiency, motivation, professional development, satisfaction, performance

oddziałują mobilizująco na pracowników i dają zapał do bardziej efektywnej pracy, a jednocześnie zapewnią im satysfakcję (Borkowska, 2004). Wyodrębnione czynniki wraz z posiadaną przez nie siłą motywacji są głównymi elementami przy budowie systemu motywacyjnego (Chmiel, 2003). Sprawnie funkcjonujący system motywacyjny wpływa na

Adres korespondencyjny: Daniel Tokarski, Państwowa Szkoła Wyższa im. Papieża Jana Pawła II w Białej Podlaskiej, Regionalne Centrum Badań środowiska, rolnictwa i technologii innowacyjnych EKO-AGRO-TECH, ul. Sidorska 107-111, 21-500 Biała Podlaska, e-mail: d.tokarski@pswbp.pl, tel.: 83344 69 21

Copyright by: Państwowa Szkoła Wyższa im. Papieża Jana Pawła II w Białej Podlaskiej, Daniel Tokarski, Agnieszka Smarzewska, Adam Szepeluk

Czasopismo Open Access, wszystkie artykuły udostępniane są na mocy licencji Creative Commons Uznanie autorstwa-użycie niekomercyjne-na tych samych warunkach 4.0 Międzynarodowe (CC BY-NC-SA 4.0, http://creativecommons.org/licenses/by-nc-sa/4.0/). 
poprawę efektywności pracy, co się przekłada na zwiększenie zysku przedsiębiorstwa, a także wywiera wpływ na zadowolenie pracowników z wykonywanych obowiązków (Glick i in., 1999).

Niniejszy artykuł ma na celu analizę wewnętrznego systemu motywacyjnego Uczelni Wyższej oraz odpowiedź na pytanie, który bodziec motywacyjny jest głównym motywatorem pracowników kadry administracyjnej Państwowej Szkoły Wyższej im. Papieża Jana Pawła II w Białej Podlaskiej. Skupiono się na definicji motywacji oraz klasyfikacji czynników motywujących pracowników do pracy.

\section{Materiał i metody}

W badaniu empirycznym wzięło udział 57 pracowników administracyjnych, co stanowiło 61\% ogółu zatrudnionych w tej grupie. Ankietowanie zostało przeprowadzone w dniach 1-14 lutego 2017 roku. Analiza wyników badania skoncentrowana była na ocenie procesu motywowania pracowników kadry administracyjnej Państwowej Szkoły Wyższej im. Papieża Jana Pawła II w Białej Podlaskiej. Badanie zrealizowano przy pomocy kwestionariusza ankiety online, na zasadzie doboru celowego respondentów, tj. każdy pracownik administracyjny otrzymał maila z linkiem do kwestionariusza ankiety wraz z prośbą o wzięcie udziału w badaniu. Udział w badaniu był dobrowolny. Operatem badań była grupa 93 osób zatrudnionych na stanowisku administracyjnym w Państwowej Szkole Wyższej im. Papieża Jana Pawła II w Białej Podlaskiej (Stan zatrudnienia pracowników kadry administracyjnej PSW na dzień 31.12.2016 r.). Formularz składał się z 14 pytań zamkniętych oraz metryczki.

Szczegółowe dane próby zawiera tabela 1.

Tabela 1. Charakterystyka badanych

\begin{tabular}{|c|c|c|}
\hline \multicolumn{2}{|c|}{ Kryterium } & $\begin{array}{l}\text { Odsetek respon- } \\
\text { dentów }\end{array}$ \\
\hline Płeć respondenta & $\begin{array}{l}\text { mężczyzna } \\
\text { kobieta }\end{array}$ & $\begin{array}{l}35 \% \\
65 \%\end{array}$ \\
\hline Wiek respondenta & $\begin{array}{l}\text { do } 25 \text { lat } \\
26-35 \text { lat } \\
36-45 \text { lat } \\
46-55 \text { lat }\end{array}$ & $\begin{array}{c}5 \% \\
47 \% \\
16 \% \\
32 \% \\
\end{array}$ \\
\hline Wykształcenie & $\begin{array}{c}\text { wyższe } \\
\begin{array}{c}\text { ukończone studia } \\
\text { podyplomowe }\end{array}\end{array}$ & $\begin{array}{l}60 \% \\
40 \%\end{array}$ \\
\hline Staż pracy ogółem & $\begin{array}{c}0-5 \text { lat } \\
6-10 \text { lat } \\
11-15 \text { lat } \\
16-20 \text { lat } \\
\text { powyżej 20 lat }\end{array}$ & $\begin{array}{l}26 \% \\
30 \% \\
22 \% \\
11 \% \\
11 \%\end{array}$ \\
\hline $\begin{array}{l}\text { Poziom dochodów } \\
\text { brutto miesięczne } \\
\text { na } 1 \text { os. w gosp. } \\
\text { domowym }\end{array}$ & $\begin{array}{c}\text { do } 1000 \text { PLN } \\
1001-1500 \text { PLN } \\
1501-2000 \text { PLN } \\
2001-2500 \text { PLN } \\
2501-3000 \text { PLN } \\
\text { powyżej } 3000 \text { PLN }\end{array}$ & $\begin{array}{c}3 \% \\
26 \% \\
28 \% \\
16 \% \\
18 \% \\
9 \%\end{array}$ \\
\hline
\end{tabular}

Jak wynika z danych empirycznych zawartych w tabeli 1, większość osób zatrudnionych to kobiety, stanowiły one 65\% pracowników kadry administracyjnej Uczelni uczestniczącej w badaniu. Mężczyźni stanowili 35\% ogółu zatrudnionych. W strukturze wiekowej badanych najliczniejsza grupę stanowili pracownicy z przedziału wiekowego 26 - 35 lat ( $47 \%$ badanych) oraz 46 - 55 lat (32 $\%$ badanych).

Charakter pracy w Uczelni odnosi się głównie do pracy umysłowej (Regulamin pracy PSW), a więc wszyscy pracownicy posiadali wykształcenie wyższe, w tym $40 \%$ badanych posiadało dodatkowo ukończone studia podyplomowe. Najliczniejsza grupa pracowników (30\%) posiadała staż pracy od 6 do 10 lat oraz 26\% staż pracy do 5 lat, można, zatem przyjąć, iż ponad połowa badanych pracuje nie dłużej niż 10 lat.

Wśród omawianych czynników ekonomicznych wymienić należy poziom osiąganych dochodów. Realizowane badania analizowały poziom dochodów brutto z uwzględnieniem miesięcznych dochodów na osobę w gospodarstwie domowym badanych poprzez subiektywną ocenę sytuacji materialnej respondentów. Największa grupa badanych osiągała dochody od 1501 do 2000 PLN na osobę w gospodarstwie domowym - 28\% badanej grupy. Kolejna grupa obejmująca $26 \%$ osiągała dochody mieszczące się w przedziale 1001 - 1500 PLN, a 18\% ankietowanych deklarowało dochody w wysokości 2001 - 2500 PLN. Blisko 16\% badanych respondentów osiągało dochody mieszczące się w przedziale 2501 - 3000 PLN, jedynie 3\% badanych odpowiedziało, że jest to mniej niż 1000 PLN. Pozostałe 9\% to osoby, w przypadku, których dochód na osobę kształtował się na poziomie powyżej 3000 PLN. Na podstawie przedstawionych danych można określić profil pracownika kadry administracyjnej Państwowej Szkoły Wyższej im. Papieża Jana Pawła II w Białej Podlaskiej. Pracownik administracji to kobieta w wieku 26-35 lat, posiadająca wyższe wykształcenie, ze stażem pracy 6-10 lat oraz posiadająca dochód brutto $\mathrm{z}$ na osobę $\mathrm{w}$ gospodarstwie domowym $\mathrm{w}$ kwocie 1501 - 2000 PLN.

\section{Wyniki badań}

W literaturze występuje wiele rozmaitych definicji motywacji, wspólnym mianownikiem jest nic innego, jak wewnętrzne poczucie człowieka w dążeniu do osiągnięcia pewnych celów, które sam sobie wyznacza (Penc, 1998). Motywacja wzbudza energię do pracy, która jest zwrócona w kierunku osiągnięcia punktu docelowego. W psychologii termin motywacji jest także nazywany zamiennie, jako motyw, popęd, instynkt, skłonność (Gros, 2012).

Pod pojęciem motywacji 26\% respondentów rozumiało, „chęć robienia czegoś, zależną od możliwości zaspokojenia przez to działanie jakiejś potrzeby danej jednostki”, 19\% twierdziło, iż jest to „stan emocjonalny popychający człowieka do osiągnię- 
cia celu”, 19\% określało motywację, jako „zespół czynników uruchamiających celowe działanie". Najmniej liczną grupę, 6\% stanowili respondenci, którzy uważali, że jest to „proces wewnętrzny, który manifestuje się w zachowaniu lub działaniu człowieka". Należy zauważyć, iż interpretacja pojęcia motywacji przez respondentów, w świetle definicji motywacji, jest poprawna i zbliżona do ogólnego pojęcia motywacji opisanej w literaturze. Kwestię tę ilustruje rycina 1.

Natomiast motywacja do pracy dla 54\% badanej populacji to „tworzenie zachęt dla pracowników do coraz wydajniejszej i bardziej efektywnej pracy",
25\% uważało, iż są to „wewnętrzne i zewnętrzne uwarunkowania zachowań ludzi w procesie pracy". Tylko dla 9\% motywacja do pracy kojarzy się z procesem powstawania i umacniania się w pracowniku świadomych decyzji (motywów). Kwestię tę przedstawiono na rycinie 2.

Można, zatem przyjąć, iż respondenci poprawnie definiują proces motywacji w organizacji. W związ$\mathrm{ku} \mathrm{z}$ tym ankietowani zostali poproszeni o ocenienie $\mathrm{w}$ jedenastostopniowej skali poziomu satysfakcji z pracy, którą wykonują, gdzie 0 oznaczało całkowity brak satysfakcji, a 10 maksymalną satysfakcję. Kwestie te przedstawiono w tabeli 2 .

\section{zbiór motywów, a motyw to przyczyna dla której człowiek zachowuje się w określony sposób \\ proces wewnętrzny, który manifestuje się w zachowaniu lub działaniu człowieka \\ zespót czynn ków uruchamiających celowe działanie \\ stan emocjonahy popychający człowieka do osiagnnięcia celu, jeśli nie ma celu nie ma motywacji \\ stan gotowości człowieka do podjęcia okr eślonego działania \\ chęć robienia czegoś, zależna od możliwości zaspokojenia przez to działanie jakiejś potrzeby danej jednostki}

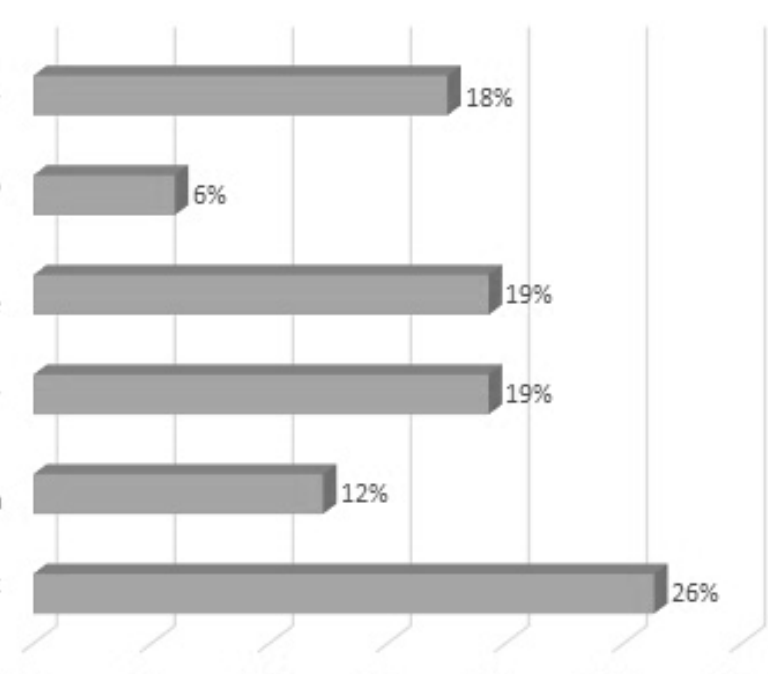

$\begin{array}{lllllll}0 \% & 5 \% & 10 \% & 15 \% & 20 \% & 25 \% & 30 \%\end{array}$

Rycina 1. Interpretacja pojęcia motywacji przez respondentów

\author{
wykonywania pracy wydajnie, rzetelnie istarannie \\ wewnętrzne i zewnețrzne uwarunkowania zachowań ludzi w \\ procesie pracy \\ tworzenie zachęt dla pracowników do coraz wydajniejszej i \\ bardziej efektywnej pracy \\ proces powstawania i umacniania się w pracowniku świadomych \\ decyzji (motywów)
}

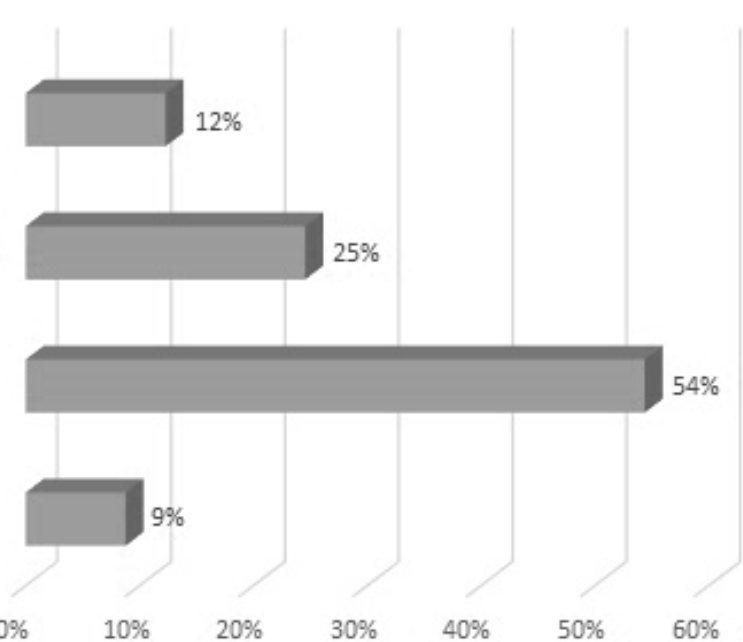

Rycina 2. Interpretacja pojęcia motywacji do pracy przez respondentów

Tabela 2. Ocena poziomu satysfakcji z wykonywanej pracy przez respondentów

\begin{tabular}{|c|c|c|c|c|c|c|c|c|c|c|c|c|}
\hline \multirow{4}{*}{$\begin{array}{l}\text { Brak } \\
\text { satysfakcji }\end{array}$} & \multicolumn{11}{|c|}{ Skala } & \multirow{4}{*}{$\begin{array}{c}\text { Maksymalna sa- } \\
\text { tysfakcja }\end{array}$} \\
\hline & 0 & 1 & 2 & 3 & 4 & 5 & 6 & 7 & 8 & 9 & 10 & \\
\hline & \multicolumn{11}{|c|}{ Odsetek respondentów } & \\
\hline & $0 \%$ & $0 \%$ & $0 \%$ & $7 \%$ & $0 \%$ & $11 \%$ & 14\% & 11\% & $25 \%$ & $26 \%$ & $6 \%$ & \\
\hline
\end{tabular}


Respondenci nie byli jednogłośni odnośnie stopnia satysfakcji ze swojej pracy. Znaczna większość badanych, bo aż 57\% udzieliła odpowiedzi, że ich praca jest bardzo satysfakcjonująca, 36\% pytanych uważało, że ich praca jest satysfakcjonująca w średnim stopniu. Zaledwie 7\% sądziło, że ich praca jest mało satysfakcjonująca. Można, zatem stwierdzić, iż pracownicy administracyjni ocenili poziom satysfakcji, jako wysoki, na poziomie średniej równej 8,14.

Ankietowani zostali również poproszeni o ocenienie stosunku aktualnego wynagrodzenia do wykonywanych obowiązków i odpowiedzialności, gdzie 0 oznaczało całkowicie nieadekwatne wynagrodzenie, a $10 \mathrm{w}$ pełni adekwatne. Szczegółowe dane przedstawiono w tabeli 3 .
Jeżeli chodzi o atmosfere panującą w miejscu pracy, to wśród badanych $28 \%$ uważało, że jest ona dobra, 35\% podkreślało, iż jest ona bardzo dobra. Tylko trzy osoby oceniło panującą atmosferę, jako złą. Blisko 1/3 ankietowanych udzieliła odpowiedzi, że jest ona wystarczająca do realizacji celów.

Kolejne pytanie dotyczyło sprawiedliwości systemu awansowania w strukturach Uczelni. Pracownicy dokonali oceny poprzez zaznaczenie jednej $\mathrm{z}$ następujacych odpowiedzi: bardzo dobrze, dobrze, dostatecznie, źle. Znaczna większość ankietowanych (63\%) oceniła system pozytywnie, 32\% oceniła go, jako dostateczny, zaledwie trzy osoby na 57 uczestniczących w badaniu uważało, iż system jest nieodpowiedni.

Tabela 3. Ocena stosunku aktualnego wynagrodzenia do wykonywanych obowiązków i odpowiedzialności przez respondentów

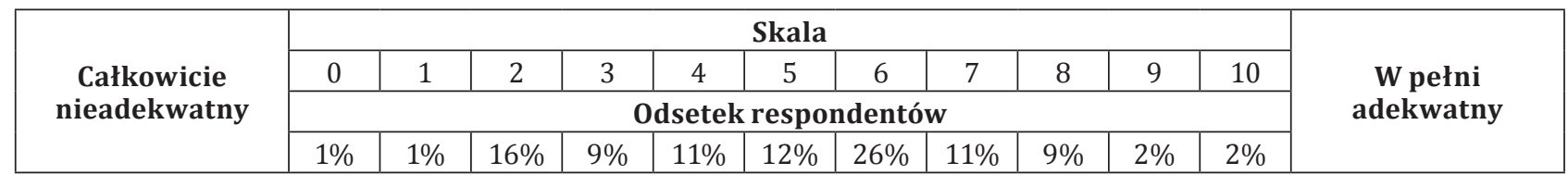

Źródło: opracowanie własne na podstawie wyników badań.

Podobnie, jak w odpowiedzi na pytanie dotyczące stopnia satysfakcji z wykonywanej pracy respondenci nie byli jednogłośni, gdyż blisko 20\% uważało, że stosunek aktualnego wynagrodzenia do wykonywanych obowiązków i odpowiedzialności jest zbliżony do całkowicie nieadekwatnego (na skali $0-2$ ), zaś $32 \%$ twierdziło, iż jest on mało adekwatny (skala 3-5). Najmniej liczną grupę, 13\% stanowią respondenci, którzy uważali, że jest on zbliżony do w pełni adekwatnego (8-10 na skali). Można, zatem stwierdzić, iż pracownicy administracyjni ocenili stosunek aktualnego wynagrodzenia do wykonywanych obowiązków i odpowiedzialności, jako średnio zadowalający, kształtujący się na średnim poziomie równym 5,18.
W karierze zawodowej pracownika Uczelni ciągłe poszerzanie swojej wiedzy jest bardzo istotne, zatem ważnym zagadnieniem było poznanie potrzeb pracowników związanych z podnoszeniem ich kwalifikacji zawodowych (Statut PSW).

Najliczniejsza grupa respondentów (58\%) odpowiedziała, że zdecydowanie odczuwało potrzebę podnoszenia swoich kwalifikacji zawodowych, zaś $28 \%$ badanych przychyliło się do odpowiedzi większości i również podkreśliło, że odczuwa taką potrzebę. Zaledwie 14\% nie odczuwa potrzeb związanych z samorealizacją i ciągłym podnoszeniem swoich kwalifikacji zawodowych.

Istnieje wiele motywatorów zachęcających ludzi do pracy. Są to motywatory płacowe oraz pozapła-

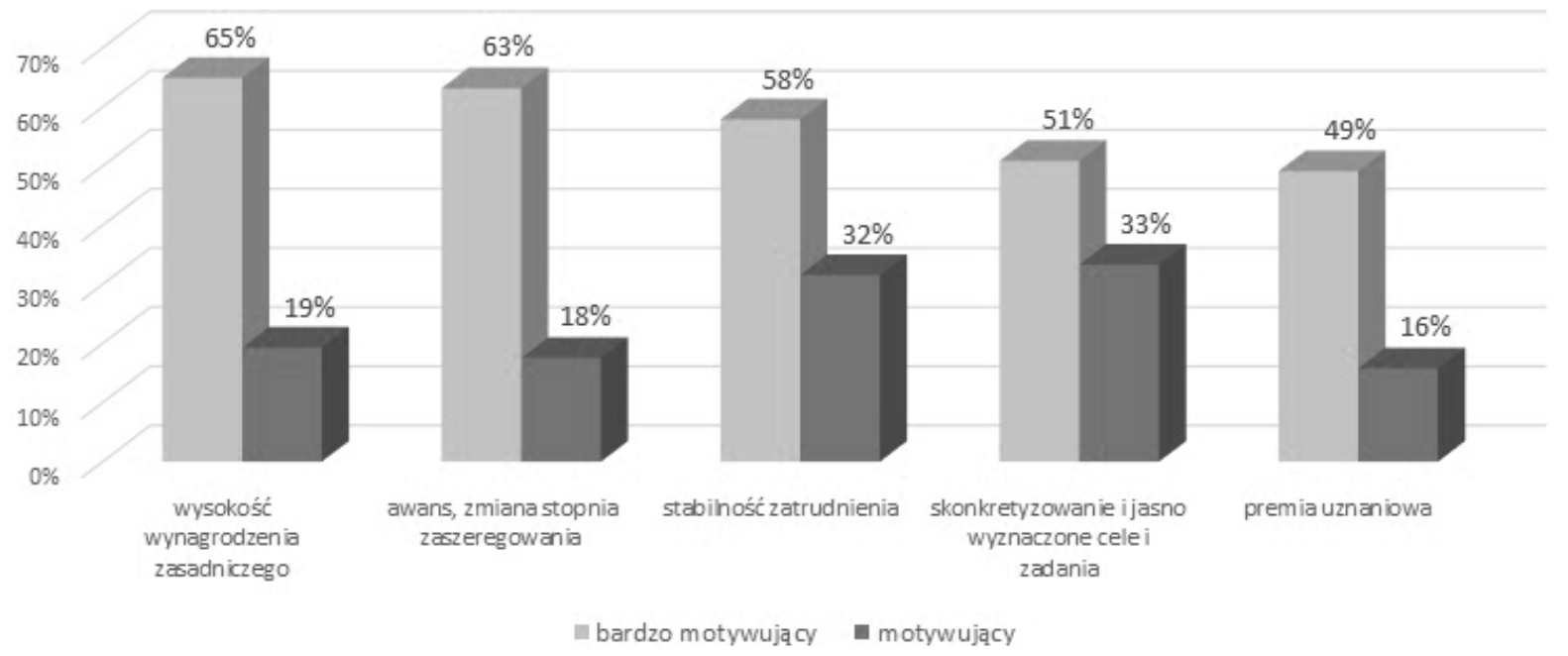

Rycina 3. Zestawienie najwyżej ocenionych czynników motywacyjnych przez respondentów Źródło: opracowanie własne na podstawie wyników badań. 
cowe. Każdy człowiek jest inny, więc również motywatory każdego z osobna się różnią (Sekuła, 2005). W jednym z pytań kwestionariusza pracownicy administracyjni zostali poproszeni o ocenienie $\mathrm{w}$ pięciostopniowej skali stopnia motywacji wymienionych czynników. Subiektywne oceny ankietowanych pracowników można podzielić na trzy grupy czynników motywacyjnych: najwyżej ocenione, o średnim znaczeniu oraz o najmniejszym znaczeniu.

Rycina 3 ilustruje najwyżej ocenione czynniki, opiniowane przez grupę kadry administracyjnej Państwowej Szkoły Wyższej im. Papieża Jana Pawła II w Białej Podlaskiej.

Najważniejszym ze wszystkich możliwych do wyboru z tabeli była wysokość wynagrodzenia zasadniczego (65\%), awans, zmiana stopnia zaszeregowania pracy $(63 \%)$ i stabilność zatrudnienia (58\%). Ponad połowa badanych stwierdziła, iż skonkretyzowane i jasno wyznaczone cele są dla nich bardzo ważne, natomiast dla $1 / 3 \mathrm{z}$ nich to ważny czynnik. Jednym z grupy najwyżej ocenionych czynników motywacyjnych był również fakt premii uznaniowej. Dla połowy badanych był to bardzo ważny bodziec zachęcający do pracy, co piąty badany uważa, że jest motywujący (Regulamin premiowania...).

Czynniki podobnie oceniane, które można określić, jako mniej ważne od wyżej wymienionych:

- uznawanie zaangażowania i sukcesów,

- nagrody, odznaczenia Rektora,

- przyjemna atmosfera w miejscu pracy,

- podnoszenie kwalifikacji poprzez szkolenia,

- dobra organizacja w miejscu pracy.

Wyżej wymienione czynniki zostały przedstawione w ujęciu procentowym na rycinie 4.

Ważnym czynnikiem motywującym wśród ankietowanych było uznawanie zaangażowania i sukcesów pracownika, aż $46 \%$ badanych wskazało powyższy czynnik, jako bardzo motywujący,

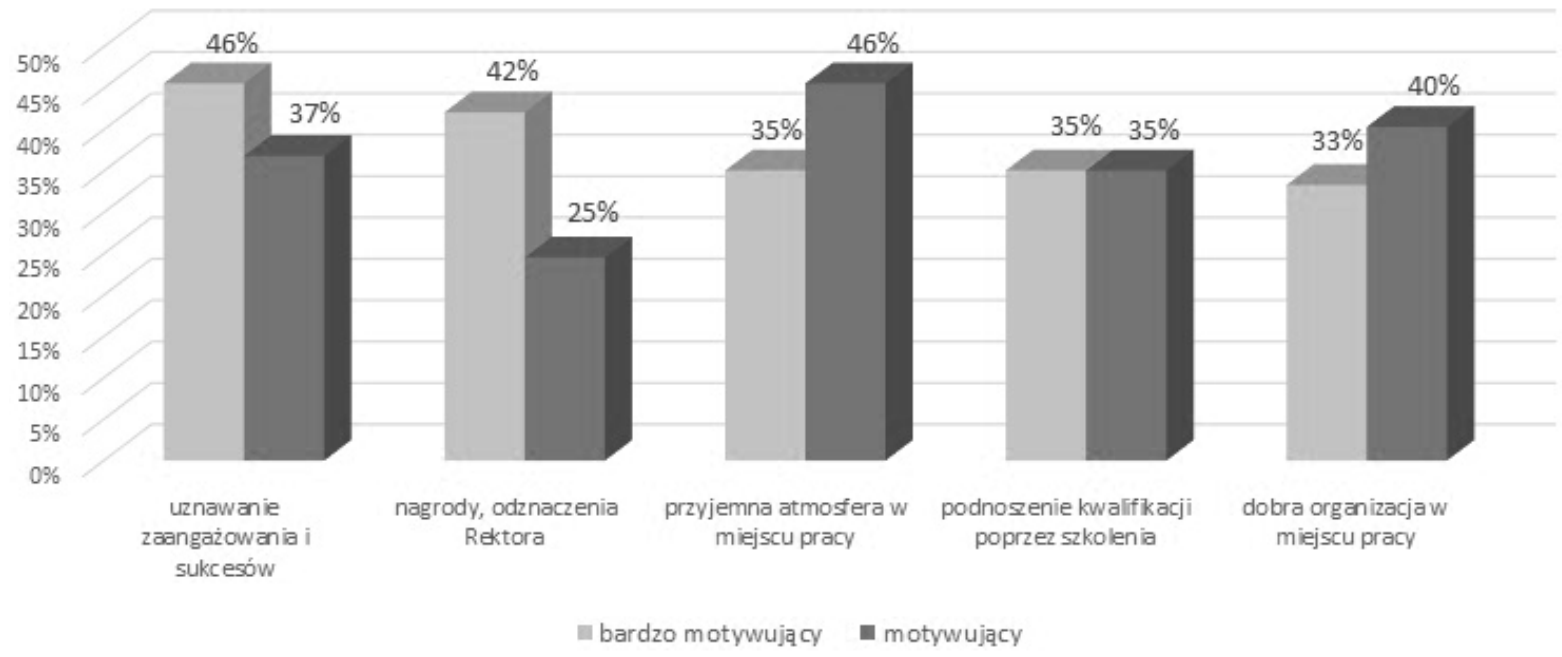

Rycina 4. Zestawienie średnio ocenionych czynników motywacyjnych przez respondentów Źródło: opracowanie własne na podstawie wyników badań.

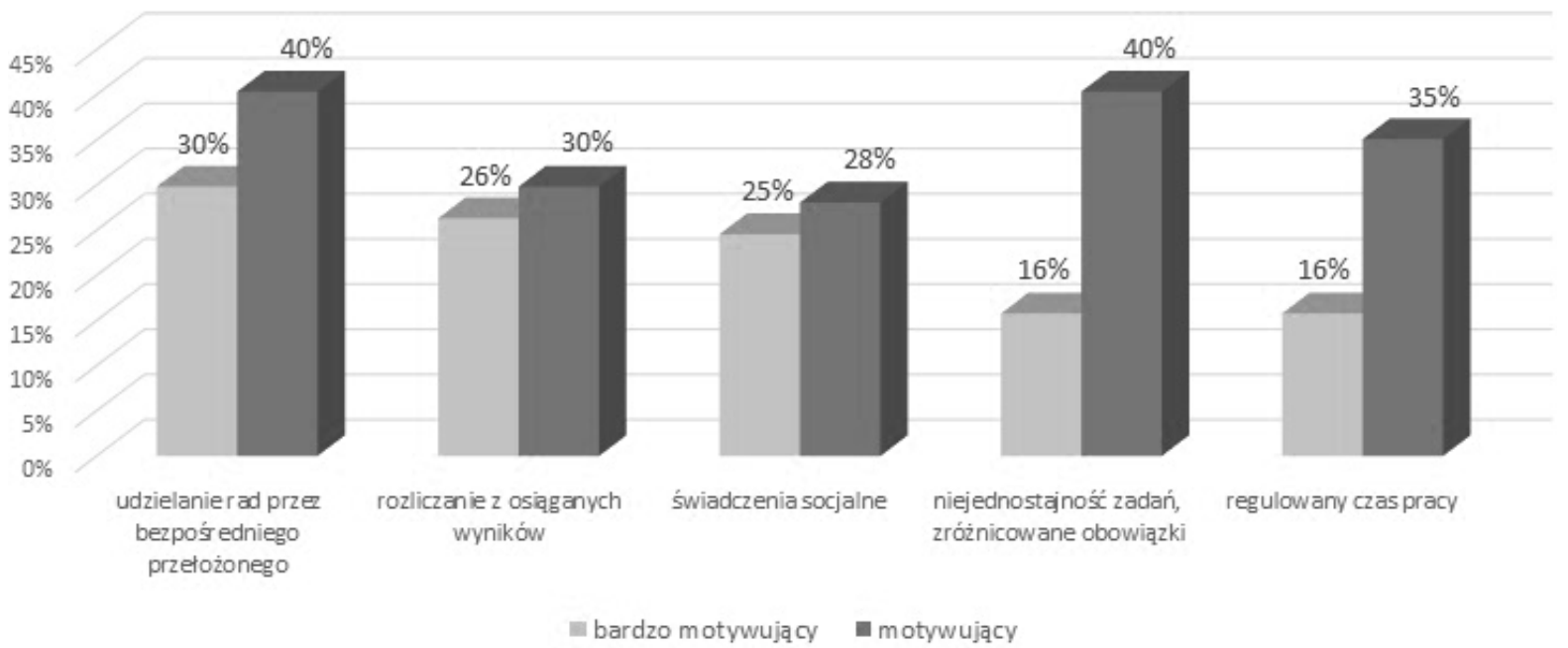

Rycina 5. Zestawienie najniżej ocenionych czynników motywacyjnych przez respondentów Źródło: opracowanie własne na podstawie wyników badań. 
a $37 \%$ z nich uważało go za motywujący. Podobnie nagrody i odznaczenia Rektora, 42\% respondentów uważało za bardzo motywujący, natomiast, co 4 badany uznał, że jest on dla niego motywujący (Regulamin Nagród Rektora PSW). Przyjemna atmosfera w miejscu pracy została oceniona przez 39\% badanych, jako czynnik bardzo motywujący, a 46\% respondentów uważało, że sprzyja motywacji. Podnoszenie kwalifikacji poprzez szkolenia oceniono, jako czynnik motywujący oraz bardzo motywujący w jednakowym stopniu, po 35\% wskazań. Dobra organizacja w miejscu pracy, jako czynnik jest motywująca dla grupy $46 \%$ osób oraz bardzo motywująca dla 33\% ankietowanych.

Rycina 5 przedstawia udział procentowy odpowiedzi respondentów dotyczący najniżej ocenionych czynników motywacyjnych. Do tych czynników należy m.in.: udzielanie rad przez bezpośredniego przełożonego, rozliczanie z osiąganych wyników, świadczenia socjalne (Regulamin przyznawania świadczeń...), niejednostajność zadań, zróżnicowane obowiązki oraz regulowany czas pracy.

Sytuacja panująca na rynku zapewne wymusza fakt, iż najbardziej mobilizującym oddziaływaniem według ankietowanych odznacza się pewność zatrudnienia, co zadeklarowało $22 \%$ badanych. Dla pracowników istotna jest także w znaczącym stopniu dobra atmosfera w pracy (16\%) oraz możliwość osobistego rozwoju - 15\%. Czynniki te są ważniejsze niż obiektywizm i sprawiedliwość w ocenie pracownika, za którym opowiedziało się $12 \%$ respondentów czy możliwość zdobycia praktyki zawodowej (8\% ogółu). Zagadnienie zilustrowano na rycinie 6.

Następne poruszone $\mathrm{w}$ badaniu zagadnienie dotyczyło utraty motywacji do pracy od czasu jej podjęcia do chwili obecnej przez pracowników kadry administracyjnej Uczelni. Znaczna większość, bo aż
72\% odpowiedziała, iż nie straciła motywacji. Natomiast pozostała część ankietowanych uznała, iż ich motywacja od czasu rozpoczęcia pracy obniżyła się.

Ankietowani zostali zapytani również o ich zadowolenie związane z pracą na obecnym stanowisku. Blisko 90\% badanych była zadowolona ze swojej pracy, natomiast pozostała część próby (11\%) nie odczuwała zadowolenia. Według ankietowanych to niskie zarobki najbardziej wpływają na spadek zadowolenia z pracy ( $32 \%$ badanych wskazało tę odpowiedź), zaś $1 / 5$ stwierdziła, iż jest to niedostrzeganie wysiłków i sukcesów pracowników przez przełożonych, 15\% uważało, że na spadek zadowolenia z pracy wpływa niemiła, nerwowa atmosfera. Czynniki te są istotniejsze niż brak możliwości rozwoju, podnoszenia kwalifikacji, awansu, za którym opowiedziało się 13\% respondentów czy przedmiotowe traktowanie oraz nadużywanie uprawnień przełożonych wobec pracowników (11\% badanych). Najmniej liczna grupa ankietowanych udzieliła odpowiedzi, iż jest to niezdrowa konkurencja (7\%) oraz brak świadczeń socjalnych (2\%). Zestawienie odpowiedzi przedstawiono na rycinie 7.

Podsumowując, pod pojęciem motywacji respondenci (26\%) rozumieją, "chęć robienia czegoś, zależną od możliwości zaspokojenia przez to działanie jakiejś potrzeby danej jednostki". Motywacja do pracy dla $54 \%$ badanej populacji to „tworzenie zachęt dla pracowników do coraz wydajniejszej i bardziej efektywnej pracy".

Respondenci nie byli jednogłośni odnoście stopnia satysfakcji ze swojej pracy, jednakże poziom satysfakcji został oceniony, jako wysoki i kształtował się na poziomie średniej równej 8,14 (w skali 0-10). Stosunek aktualnego wynagrodzenia do wykonywanych obowiązków i odpowiedzialności został oceniony, jako średnio zadowalający, na poziomie równym 5,14 (w skali 0-10).

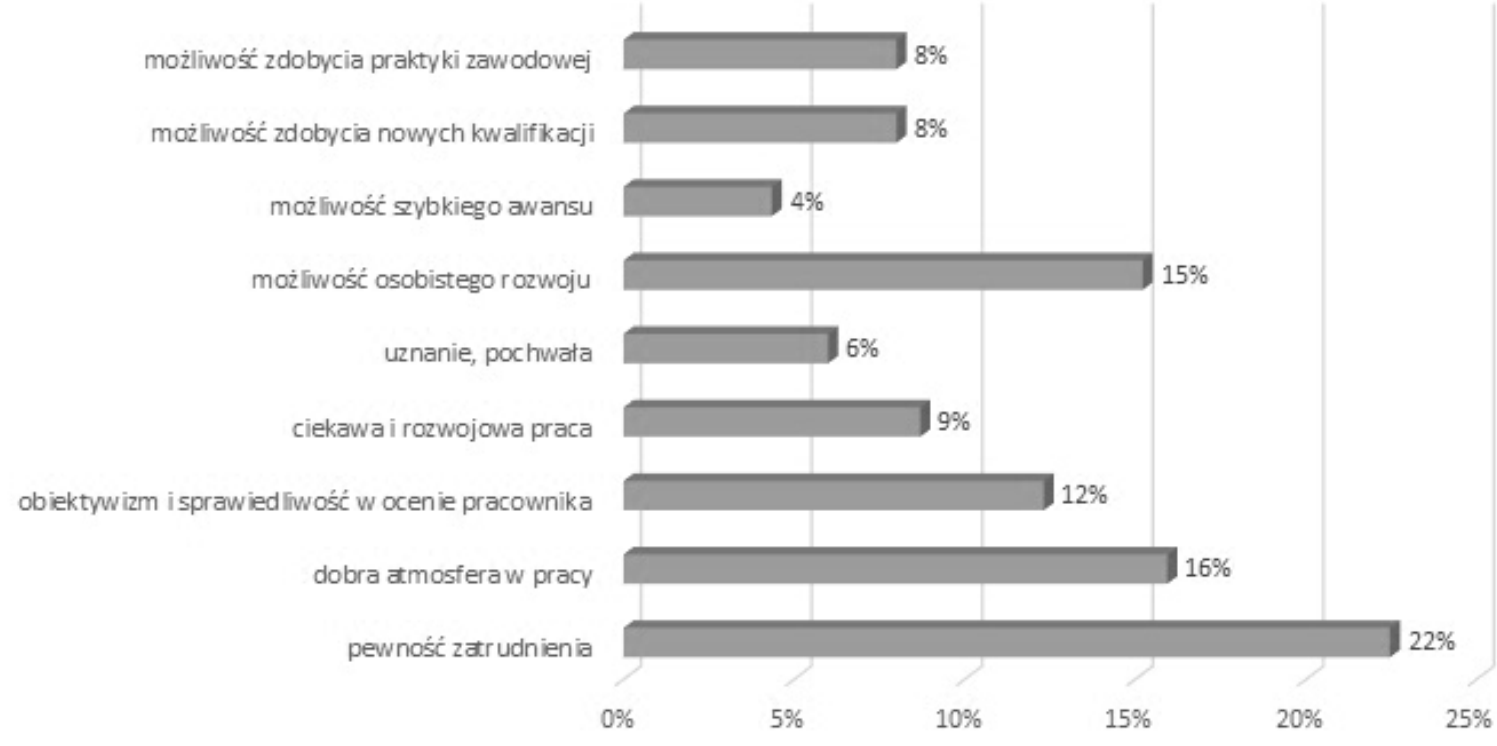

Rycina 6. Stopień oddziaływania niematerialnych środków motywacyjnych w opinii respondentów Źródło: opracowanie własne na podstawie wyników badań. 


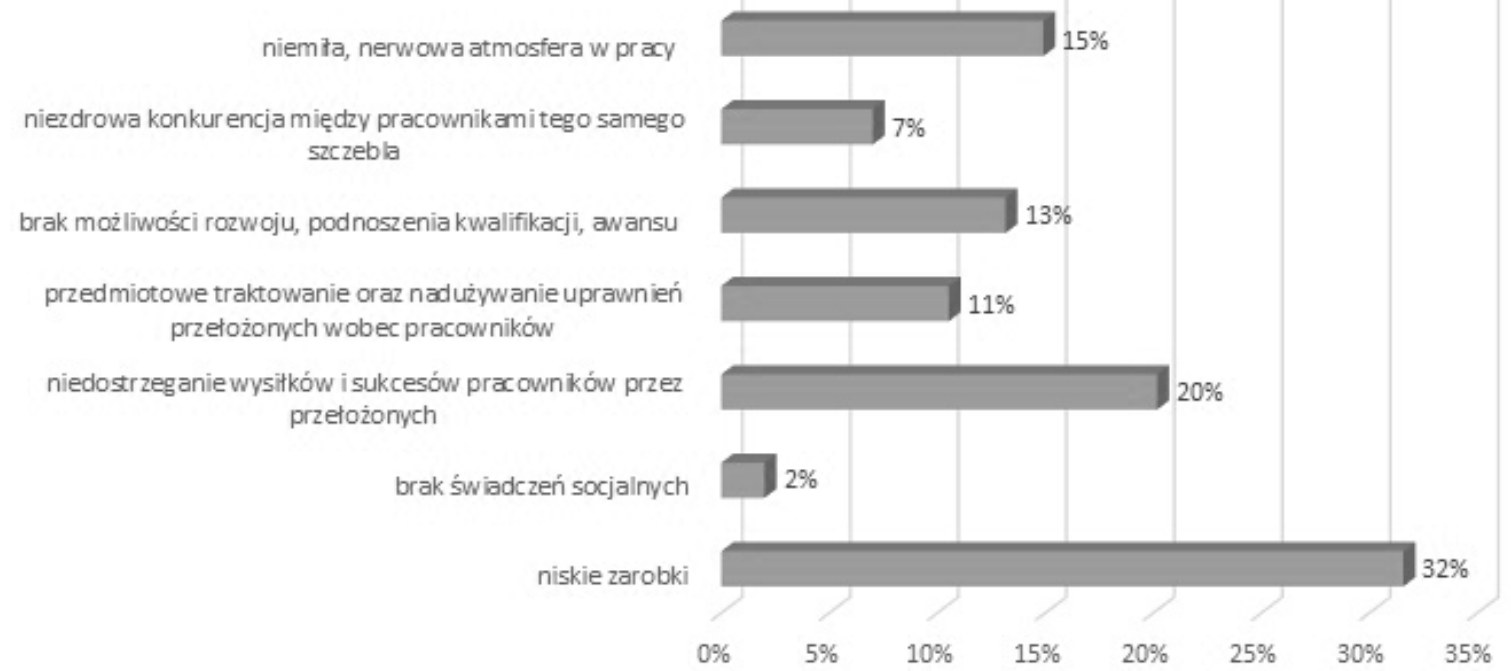

Rycina 7. Ocena najistotniejszego czynnika wpływającego na spadek zadowolenia z pracy przez respondentów Źródło: opracowanie własne na podstawie wyników badań.

Atmosfera pracy w PSW została oceniona przez pracowników, jako bardzo dobra. Sprawiedliwość systemu awansowania w strukturach Uczelni została oceniona przez pracowników w znacznej mierze pozytywnie.

W karierze zawodowej pracownika Uczelni ciągłe poszerzanie swojej wiedzy jest bardzo istotne, znaczna większość pracowników (58\%) odpowiedziała, że zdecydowanie odczuwa potrzebę podnoszenia swoich kwalifikacji zawodowych.

Istnieje wiele motywatorów zachęcających ludzi do pracy (Nyczyk, 2005). W badanej grupie najwyżej oceniono czynniki motywacyjne, takie jak wysokość wynagrodzenia zasadniczego, awans, zmiana stopnia zaszeregowania pracy, stabilność zatrudnienia, skonkretyzowane i jasno wyznaczone cele oraz fakt przyznawania premii uznaniowej. Najistotniejszymi elementami pozapłacowymi wewnętrznego systemu motywacyjnego okazało się być: pewność zatrudnienia, dobra atmosfera w pracy, możliwość osobistego rozwoju oraz obiektywizm i sprawiedliwość w ocenie pracownika.

Znaczna większość, bo aż $72 \%$ badanych nie straciło motywacji do pracy oraz blisko $90 \%$ badanych było zadowolonych ze swojej pracy. Ocenie poddano także, czynniki wpływające na spadek zadowolenia z pracy, według ankietowanych to niskie zarobki najbardziej wpływają na spadek zadowolenia z pracy oraz niedostrzeganie wysiłków i sukcesów pracowników przez przełożonych.

\section{Dyskusja i wnioski}

Artykuł obejmuje zakres tematyki motywacji oraz badania własne przeprowadzone w Państwowej Szkole Wyższej im. Papieża Jana Pawła II w Białej Podlaskiej. System motywacji PSW oparty jest o akty prawne oraz wewnątrzuczelniane dokumenty, takie jak Statut czy Regulamin Pracy. Motywacja jest bar- dzo ważna w życiu każdego człowieka, dlatego ten wątek jest intrygujący i zasługuje na uwagę.

Zasadniczym celem badań była odpowiedź na pytanie, jakie są główne bodźce motywujące pracowników administracyjnych do pracy. Realizując cel pracy dokonano przeglądu literatury i przeprowadzono badania własne przy pomocy stworzonego narzędzia, jakim był kwestionariusz ankiety. Analiza materiału badawczego pokazała, iż system motywacji obowiązujący na PSW jest znany pracownikom. Biorąc pod uwagę odpowiedzi badanych, należałoby w przyszłości rozważyć możliwość modyfikacji wewnętrznego systemu motywacyjnego Uczelni.

Badania własne przeprowadzane za pomocą kwestionariusza ankiety wykazały, iż głównymi czynnikami motywującymi pracowników administracyjnych do pracy są m.in.: wysokość wynagrodzenia zasadniczego, możliwość awansu, zmiana stopnia zaszeregowania, stabilność zatrudnienia, skonkretyzowane i jasno wyznaczone cele oraz premia uznaniowa. Płacowe czynniki motywacyjne są dla respondentów kluczowe w procesie samorealizacji i zadowolenia z wykonywanej pracy. Oznacza to, że pracownicy najbardziej cenią sobie fakt stałej, dobrze płatnej pracy z możliwością rozwoju.

Artykuł porusza bardzo istotną problematykę, dotyczącą sposobu formowania działalności, koniunktury pracy, aby sprzyjały rozwojowi zatrudnionego oraz wydajnemu wykorzystaniu jego zdolności i powołania. Przy czym wyjątkowo istotne jest, aby pracownik doznał i utrzymał satysfakcję z pracy (Król i in., 2007). Wysoce istotne jest, by system motywacyjny korespondował oraz współgrał z innymi procesami zarządzania. Jedynie, gdy będzie on uzupełniającym narzędziem komunikacyjno-motywującym, będzie miał prawdopodobieństwo wykonywać stawiane przed nim oczekiwania (Locke i in., 1984). 


\section{Literatura:}

1. Borkowska, S. (2004). Motywować skutecznie. Warszawa: IPISS.

2. Chmiel, N. (2003). Psychologia pracy i organizacji. Gdańsk: Gdańskie Wydawnictwo Psychologiczne.

3. Glick, A., Tarczyńska, M. (1999). Motywowanie pracowników. Warszawa: Polskie Wydawnictwo Ekonomiczne.

4. Gros, U. (2012). Zachowania organizacyjne w teorii i praktyce zarzadzania. Warszawa: Wydawnictwo Naukowe PWN.

5. Król, H., Ludwiczyński, A. (2007). Zarządzanie zasobami ludzkimi. Warszawa: Wydawnictwo Naukowe PWN.

6. Locke, G., Latham, G.P. (1984). Goal Stetting: A Motivational Technique That Works. New York: Englewood Cliffs, Prentice-Hall.

7. Nyczyk, T. (2005). Wynagrodzenie za pracę. Kraków: Arden.

8. Penc, J. (1998). Motywowanie w zarządzaniu. Kraków: Wydawnictwo Profesjonalnej Szkoły Biznesu.

9. Sekuła, Z. (2005). Wynagrodzenia zmienne i rzeczowe. Kraków: Oficyna ekonomiczna.

\section{Akty prawne}

10. Ustawa z dnia 27 lipca 2005 r. - Prawo o szkolnictwie wyższym (Dz. U. Nr 164, poz. 1365 z późn. zm.), art. 155. Pobrane z: http://isip.sejm.gov.pl/DetailsServlet?id=WDU20051641365

11. Regulamin Nagród Rektora PSW, Pobrane z: http://bip.pswbp.pl/?cid=27\&bip_id=2266

12. Regulamin pracy PSW, Pobrane z: http://bip.pswbp.pl/?cid=27\&bip_id=1807

13. Regulamin premiowania pracowników niebędących nauczycielami akademickimi PSW, Pobrane z: http:// bip.pswbp.pl/?cid=27\&bip_id=2721

14. Regulamin przyznawania świadczeń pomocy materialnej z własnego funduszu stypendialnego dla studentów i pracowników $P S W$, Pobrane z: http://bip.pswbp.pl/?cid=27\&bip_id=2560

15. Statut PSW, Pobrane z: http://bip.pswbp.pl/?cid=104\&bip_id=2808 